\title{
EFFECTS OF FRUITING ON THE GROWTH OF ARABICA COFFEE TREES AS RELATED TO CARBOHYDRATE AND NITROGEN STATUS AND TO NITRATE REDUCTASE ACTIVITY
}

\author{
JOSÉ A.T. AMARAL ${ }^{1}$, FÁBIO M. DA MATTA² AND ALEMAR B. RENA ${ }^{3}$
}

Departamento de Biologia Vegetal, Universidade Federal de Viçosa, 36571-000 Viçosa, MG, Brasil

\begin{abstract}
Active vegetative and reproductive growth in field-grown trees of Coffea arabica L. in Viçosa (20 $45^{\circ}$ 'S, $650 \mathrm{~m}$ altitude), south-eastern Brazil, occur concurrently. The overall patterns of branch growth and leaf area gain were to a certain extent altered by fruit removal, with growth rates being remarkably greater in de-fruited trees. The content of $\mathrm{N}^{-\mathrm{NO}_{3}}$ was not affected by fruiting, whilst that of amino-N was greater in de-fruited than fruiting trees most of the time, but the differences were not large enough to have significantly contributed to the increased growth rates in de-fruited trees. Leaf nitrate reductase activity was greater in plants bearing fruit than in non-bearing ones most of the time; activity was roughly inversely associated with growth. Although the roots contained much more nitrate than the leaves, the root nitrate reductase activity was much lower and not affected by fruiting. Much of the restrictive effects of fruiting on vegetative growth appeared to be associated to starch exhaustion, in addition to the outstanding effect of supra-optimum temperatures per se.
\end{abstract}

ADDITIONAL INDEX TERMS: Amino acids, ammonium, Coffea arabica, nitrate, starch, sugars, temperature.

\section{EFEITOS DA FRUTIFICAÇÃO SOBRE O CRESCIMENTO DO CAFEEIRO ARÁBICO EM RELAÇÃO AO SUPRIMENTO DE CARBOIDRATOS DE NITROGÊNIO E À ATIVIDADE DA REDUTASE DO NITRATO}

RESUMO - A fase ativa do crescimento vegetativo e o crescimento reprodutivo do cafeeiro (Coffea arabica L.) ocorrem concomitantemente em Viçosa $\left(20^{\circ} 45^{\prime} \mathrm{S}\right.$; altitude, $\left.650 \mathrm{~m}\right)$, Sudeste do Brasil. Os padrões gerais de crescimento de ramos e de ganho de área foliar foram ligeiramente alterados pela remoção dos frutos. As taxas de crescimento foram significativamente maiores nos cafeeiros sem frutos. $\mathrm{O}$ conteúdo de $\mathrm{NO}_{3}-\mathrm{N}$ não foi afetado pela presença de frutos, ao passo que o conteúdo de amino-N foi, em geral, maior em árvores sem frutos. Todavia, as diferenças nos níveis de amino-N em resposta à frutificação não foram expressivas, de sorte que é pouco provável que os maiores níveis de amino-N tenham contribuído para um maior crescimento dos cafeeiros sem frutos. Nas folhas, a atividade da

Received: 31/3/1999 - Accepted: 9/2/2001

1. Departamento de Fitotecnia, Universidade Federal do Espírito Santo, 29500-000 Alegre, ES, Brasil

2. Corresponding author. Departamento de Biologia Vegetal, Universidade Federal de Viçosa, 36571-000 Viçosa, MG, Brasil

3. Empresa de Pesquisa Agropecuária do Estado de Minas Gerais, 36570-000 Viçosa, MG, Brasil 
redutase do nitrato foi maior nas plantas com frutos em relação àquelas sem frutos; a atividade da enzima mostrou-se, aparentemente, relacionada de modo inverso com o padrão de crescimento. As raízes apresentaram um conteúdo de $\mathrm{NO}_{3}-\mathrm{N}$ consideravelmente superior ao das folhas, mas com uma atividade da redutase do nitrato significativamente menor, sem qualquer relação com frutificação e crescimento. Os efeitos restritivos da frutificação sobre o crescimento vegetativo pareceram estar associados principalmente à exaustão das reservas de amido, em adição aos efeitos de temperaturas supra-ótimas per se.

TERMOS ADICIONAIS PARA INDEXAÇÃO: Açúcares, amido, aminoácidos, amônio, Coffea arabica, nitrato, temperatura.

\section{INTRODUCTION}

Several factors in Arabica coffee growing zones worldwide have been indicated as causes of the tree growth periodicity. These include drought, temperature, photoperiod, soil $\mathrm{N}$ availability, and reproductive growth (Maestri and Barros, 1977). In Viçosa, southeastern Brazil, with climate typically alternating a wet, warm and a dry, cool season, the coffee tree shows an active and a quiescent growth phase accompanying the fluctuations in temperature (Barros \& Maestri, 1974; Da Matta et al., 1999), but not rainfall since irrigation alters neither the pattern nor the rate of growth (Mota et al., 1997).

Coffee shoot growth is not continuous during the active growing season. Temporary depression in growth of shoots has been attributed to high temperatures (Gindel, 1962; Barros \& Maestri, 1974; Barros et al., 1997). In addition, other factors such as nutrient leaching and daytime water stress due to a high evaporative demand are also invoked to account for by growth oscillations (Cannel, 1985). However, according to Barros et al. (1997), internal water tension is unlikely to be an imporant factor controlling the coffee plant growth cycle. Despite these considerations, relatively little attention has been devoted to the understanding of vegetative growth behaviour during the growing season on physiological basis. This is of considerable relevance because flower buds in Arabica coffee are initiated on the same wood only once (Rena et al., 1994), thus the amount of growth produced in the current season will to a large extent determine the crop yield the following growing season.
The relationships between vegetative and reproductive growth in coffee are rather complex and poorly understood. In most regions, rapid vegetative growth and fruit development appear to take place at different times, suggesting a seemingly opposition or competition between the two processes. On the other hand, fast vegetative and reproductive growth may occur concurrently, as in Viçosa and in Guatemala (Maestri \& Barros, 1977; and references therein). As the coffee tree under plantation conditions seems not to exert a fine control on the fruit sink strength in the balance with carbohydrates and mineral resources (Cannel, 1985), both resources might be diverted to the fruit at the expenses of the shoot apices and root-trunk system, sometimes to the point of causing overbearing dieback (Cannel \& Huxley, 1969). However, if both the reserves and the supply of currently carbohydrates are high, or if trees fruit lightly, then vegetative growth would not be expected to be greatly restrained.

In addition to diverting large amounts of carbohydrates, coffee fruits, particularly during their rapid expansion phase, may draw over 95\% of the current total uptake of $\mathrm{N}$ (Cannel, 1985), thus not rarely bringing about $\mathrm{N}$-deficiency symptoms in foliage and restricting vegetative growth. In this study, changes in both carbohydrate and $\mathrm{N}$ status were followed during the growing season in order to gain a better understanding concerning fruiting effects on vegetative growth. The activity of nitrate reductase (NR), considered as the biochemical rate-limiting step in the $\mathrm{NO}_{3}-\mathrm{N}$ assimilation pathway (Campbell, 1999), was also monitored, taking into account that its fluctuations might be involved in the control of growth 
periodicity and protein production in perennial plants (Solomonson \& Barber, 1990). In addition, since some early investigations (e.g., Montoya et al., 1961; Bravo-C. \& Fernandez, 1964) reported that coffee trees grow better in response to urea than to nitrate fertilisers, it was investigated whether any relation between growth and those different $\mathrm{N}$ sources there indeed exists.

\section{MATERIAL AND METHODS}

\section{Plant material and management}

The experiments were conducted during the 1987-88 growing season with eight-year-old field-grown trees of Coffea arabica L. cv. Red Catuaí, spaced $3.0 \times 2.0 \mathrm{~m}$, with two plants per hole, growing as a hedgerow on a Cambic Yellowish Red Podzolic soil, terrace phase, in Viçosa $\left(20^{\circ} 45^{\prime} \mathrm{S}, 650 \mathrm{~m}\right.$ altitude), southeastern Brazil. The trees were unshaded, clean-weeded, and regularly flood-irrigated. Fertilisation per hole during trials was accomplished with $120 \mathrm{~g} \mathrm{~N}$ supplied as sodium nitrate or urea, $7.0 \mathrm{~g} \mathrm{P}$ as single super phosphate, and $52 \mathrm{~g} \mathrm{~K}$ as potassium chloride, split into three ( $\mathrm{P}$ and $\mathrm{K})$ or four $(\mathrm{N})$ applications. In addition, micronutrient sprayings were also applied. Coffee leaf miner (Leucoptera coffeella) and coffee berry borer (Hypothenemus hampei) were controlled with sprayings of Ethion $50 \mathrm{CE}$ and Endosulfan, respectively. The experiment was laid out in a split plot design with five replicates, with two $\mathrm{N}$ sources as the main plots and fruiting level treatment applied to the sub-plots. Plots were separated from each other by two rows of plants. Each sub-plot was constituted by 10 plants. Entire trees of half of each sub-plot were de-fruited just before accomplishment of the experiments.

\section{Growth measurements}

Fourteen primary plagiotropic branches from the upper third of the plant canopies were tagged in each sub-plot for periodical length measurements. Leaf area $(L)$ was estimated through the equation $L=0.667 \mathrm{X}$, in which the independent variable is the rectangle circumscribed to the leaf (Barros et al., 1973).

\section{Environment parameters}

Air temperature $\left(T_{\mathrm{a}}\right)$ and relative humidity were recorded with a thermohygrograph (model 252, Lambrecht Recording Instruments, Göttingen, Germany) housed in a standard meteorological shelter in the experimental area. Total daily times with $T_{\mathrm{a}}>24^{\circ} \mathrm{C}$ were integrated from the temperature chart.

\section{Biochemical assays}

Biochemical determinations were carried out in fully expanded leaves of the third pair from the apex of lateral branches from the upper third of the coffee trees, collected at about 09:00 h. Roots ( $\leq 0.6 \mathrm{~mm}$ diameter) were withdrawn from the 0 $0.20 \mathrm{~m}$ soil layer in an area corresponding to the canopy projection, and collected at about 14:00 h. Further details on sampling were described in Da Matta et al. (1999).

To extract carbohydrates, $\mathrm{NH}_{4}-\mathrm{N}$ and amino-N, plant tissues were ground in $80 \%$ ethanol at $60^{\circ} \mathrm{C}$; the finely powdered material was then centrifuged at $2000 \times g$ for $5 \mathrm{~min}$ at $20^{\circ} \mathrm{C}$. The pellet was submitted to three successive extractions with $80 \%$ ethanol at $60^{\circ} \mathrm{C}$. The supernatants were combined and subsequently purified using chloroform. After partition, the aqueous phase was collected and evaporated to dryness at $45^{\circ} \mathrm{C}$ under vacuum. The residue was resuspended in $5 \mathrm{~mL}$ distilled water, which constituted the aqueous extract for analysis. The $\mathrm{NH}_{4}-\mathrm{N}$ was quantified according to Cataldo et al. (1974), and amino-N following a method modified from Moore and Stein (1954) by Da Matta et al. (1999). Reducing sugars were determined by the method of Nelson (1944), and total soluble sugars according to McCready et al. (1950), with a few modifications, as follows: appropriate aliquots from the aqueous extract were placed into capped tubes under ice bath in a $1 \mathrm{~mL}$ volume adjusted with distilled water, plus $5 \mathrm{~mL}$ anthrone reagent $(1 \%$ anthrone in 
$28 \mathrm{~N}$ sulfuric acid). The mixture was stirred and allowed to react under a boiling water bath over 12 min. After heating, tubes were cooled in an ice bath, and the resulting absorbance was read at 620 $\mathrm{nm}$ using glucose as standard. Non-reducing sugars were calculated as the difference between total soluble and reducing sugars. The pellet remaining after extraction of both $\mathrm{N}$ compounds and soluble sugars was solubilised by acid hydrolysis with percloric acid according to McCready et al. (1950), for starch analysis. The starch content of the supernatant was assessed spectrophotometrically following the same procedure as used for total soluble sugars assay. Starch was expressed as glucose equivalents multiplied by 0.9 .

Nitrate- $\mathrm{N}$ was extracted from dried, 60mesh ground tissues with distilled water during $4 \mathrm{~h}$ at $45^{\circ} \mathrm{C}$, and quantified as stated by Cataldo et al. (1975). Nitrate reductase activity was assayed by an in vivo method according to Jaworski (1971), with the modifications given in Da Matta et al. (1999).

\section{RESULTS AND DISCUSSION}

Regardless of whether the coffee trees were $\mathrm{N}$-fertilised with $\mathrm{N}-\mathrm{NO}_{3}$ or $\mathrm{N}$-urea, growth rates, carbohydrate and $\mathrm{N}$ status, and $\mathrm{NR}$ activity showed identical patterns. Therefore, data are presented for the $\mathrm{N}-\mathrm{NO}_{3}$ fertilisation only.

The active phase of vegetative growth of coffee tree in Viçosa parallels the warm, rainy period, from mid-September through mid-March (Barros and Maestri, 1974), with the first growth flushes coinciding with blossoming. After fertilisation of the ovary by mid to late September, fruit growth is negligible by 6 to 8 weeks, followed by a period of rapid growth, from about 6 to 16 weeks after blossoming, until the green berry approaches its final size (Maestri and Barros, 1977; Cannel, 1985). Therefore, active vegetative and reproductive growth in Viçosa occur concurrently.

The overall patterns of branch growth and leaf area gain were to some extent altered by fruit removal. As Figure 1 shows, both leaf and branch growth continued in de-fruited trees over the period of slow growth in late December and January in trees bearing fruit. In de-fruited trees, growth rates increased from early November until a maximum by mid-December. Subsequently, growth declined slightly by late December, and then more appreciably by late January, then increasing until mid-February, and falling down afterwards. A similar fluctuation was observed for leaf area increase. In fruiting trees, branch and leaf growth fell down from late November, and had almost ceased through January (Figure 1); thereafter growth resumption began, but at significantly lower rates than those of de-fruited trees. Developing fruits seem to have priority demand for assimilates from adjacent leaves or even from farthest ones of other branches (Clowes and Wilson, 1977), and may therefore draw large amounts of assimilates, thus restraining growth of vegetative organs. In effect, in Kenya, during the rapid phase of fruit growth, fruits may account for from 60 to $90 \%$ of the measured dry matter increment of the branches, and the dry mass of new vegetative growth produced by fruitless branches was almost three times as large as that produced by fruiting ones (Cannel, 1971).

Despite the large differences in growth rates between fruiting and de-fruited trees reported here, no significant effect of fruit on leaf area gain was found by Mota et al. (1997) working with the same trees used in the present experiment in the preceding year, whereas branch growth was only slightly depressed by fruits. This seeming divergence could have resulted from differences in fruit load which varies biennially in coffee. In fact, the trees bore heavily in the present work, conversely to what happened in the Mota and coworkers' study.

According to Alègre (1959), the range of mean $T_{\text {a }}$ favourable for coffee tree growth is 16 to $23^{\circ} \mathrm{C}$, with an optimum lying from 18 to $21^{\circ} \mathrm{C}$. Above $24^{\circ} \mathrm{C}$, the Arabica coffee growth can be severely restrained (Nunes et al. 1968). In the present work, only in the first week of January $T_{\mathrm{a}}$ lay within the optimum range, with few hours above $24^{\circ} \mathrm{C}$ (Figure 2), but during this period growth was depressed, particularly in fruiting trees (Figure 1). 


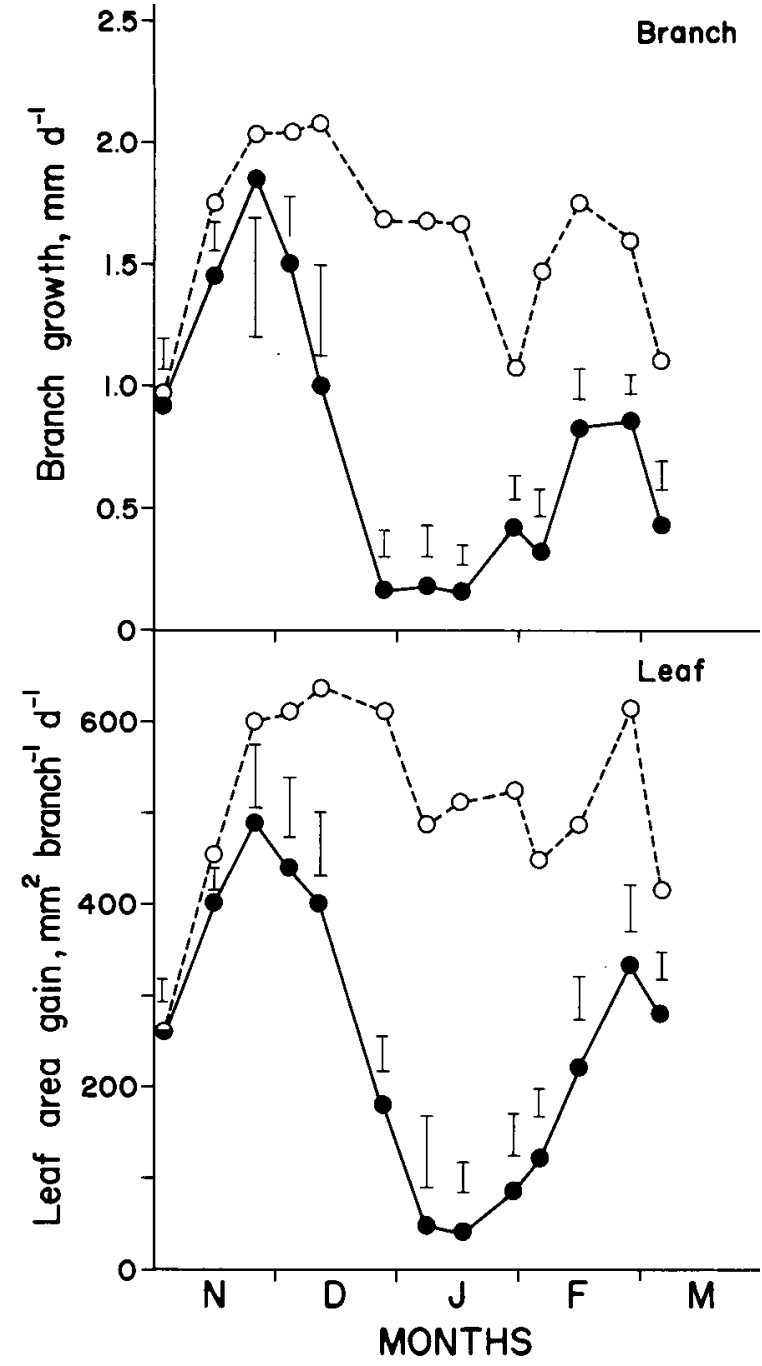

FIGURE 1 - Growth rates of branches (upper) and leaf area gain per plagiotropic branch (lower) of fruiting (solid line) and de-fruited (dotted line) coffee trees, from November 1987 through early March 1988. Bars represent the least statistical difference at a given time, at $P=0.05$. Each point is a mean of 14 measurements.

On the other hand, $T_{\mathrm{a}}$ was relatively high by mid-November although growth rates were nearly at a maximum then. This apparent discrepancy could be circumstantially attributed to the greater starch content in both leaves and roots in late November than in early January (Figure 3), which might have been used to support growth; conversely, effects of favourable $T_{\mathrm{a}}$ for growth in early January would be dissembled by starch shortage. Thereafter, particularly from mid-January through early February, $T_{\mathrm{a}}$ increased appreciably (Figure 2), which might have contributed to diminish growth (Figure 1). According to Nunes et al. (1968) coffee, for each degree above $24^{\circ} \mathrm{C}$ a decline of about $10 \%$ in dry matter production is to be expected, and above $34^{\circ} \mathrm{C}$, dry matter production could approach zero. It should be stressed that during the warmer periods temperature in coffee leaves in Viçosa can reach values as high as $40^{\circ} \mathrm{C}$ (Barros et al., 1997), thus likely bringing about a leaf negative carbon balance.

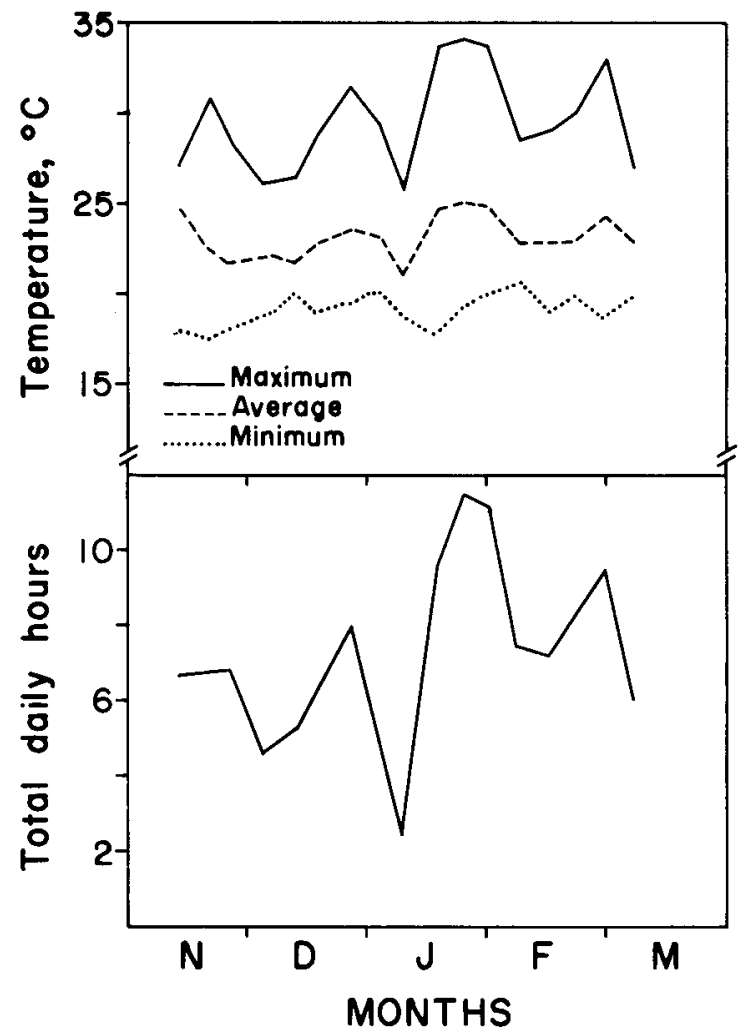

FIGURE 2 - Upper: Time course of mean weekly air temperature. Lower: Total daily mean number of hours with air temperature above $24^{\circ} \mathrm{C}$, from November 1987 through early March 1988. 
Starch content fluctuated similarly in both leaves and roots, but its levels were almost always greater in de-fruited trees than in fruiting ones (Figure 3). Starch probably decreased while supporting the vegetative growth and, to a greater extent, the carbohydrate demand by developing fruits. Decreases in starch occurred in both leaves and roots, an evidence that growing trees may withdraw reserves from the root-trunk system and leaves concurrently (Nutman, 1933; Wormer and Egabole, 1965). In early January, leaf starch was almost completely depleted, in parallel to the strongest depression in growth rates of fruiting plants; hence, the actual photosynthesis should have proceeded to a greater extent to support the continued development of fruits.

Regardless of the fruit presence, the content of total soluble sugars in both leaves and roots remained practically unchanged throughout the growing season (Figure 3), and thus it could not be associated to decline in growth rates. However, as suggested from the data of Figure 3, a possible conversion of reducing into nonreducing sugars had taken place. Such a conversion might represent a capacity of the plant in buffering the supply of carbohydrates to the growing points.

The activity of NR in leaves fluctuated similarly in both fruiting and de-fruited trees (Figure 4). The data presented in Figures 1 and 4 indicate an inverse relation between NR activity and growth. Enzyme activity was higher in the slower growing fruiting trees than in the faster growing de-fruited trees and increased in both as growth slowed during mid-December and January. Roots, despite having much more $\mathrm{NO}_{3}-\mathrm{N}$ than leaves, showed lower NR activity, irrespective of fruiting. In any case, both root NR activity and $\mathrm{NO}_{3}$-N levels varied only slightly (Figure 4) so that they would hardly influence the shoot growth changes. In general, the greatest leaf activities of NR took place from early January through early February, paralleling periods with high $T_{\mathrm{a}}$ (Figure 2) and high evaporative demand (not shown). These conditions probably led to an increase in ascent of water, and thus to an enhanced inflow of $\mathrm{NO}_{3}-\mathrm{N}$ to leaves that, in turn, might have brought about a rise in NR activity.

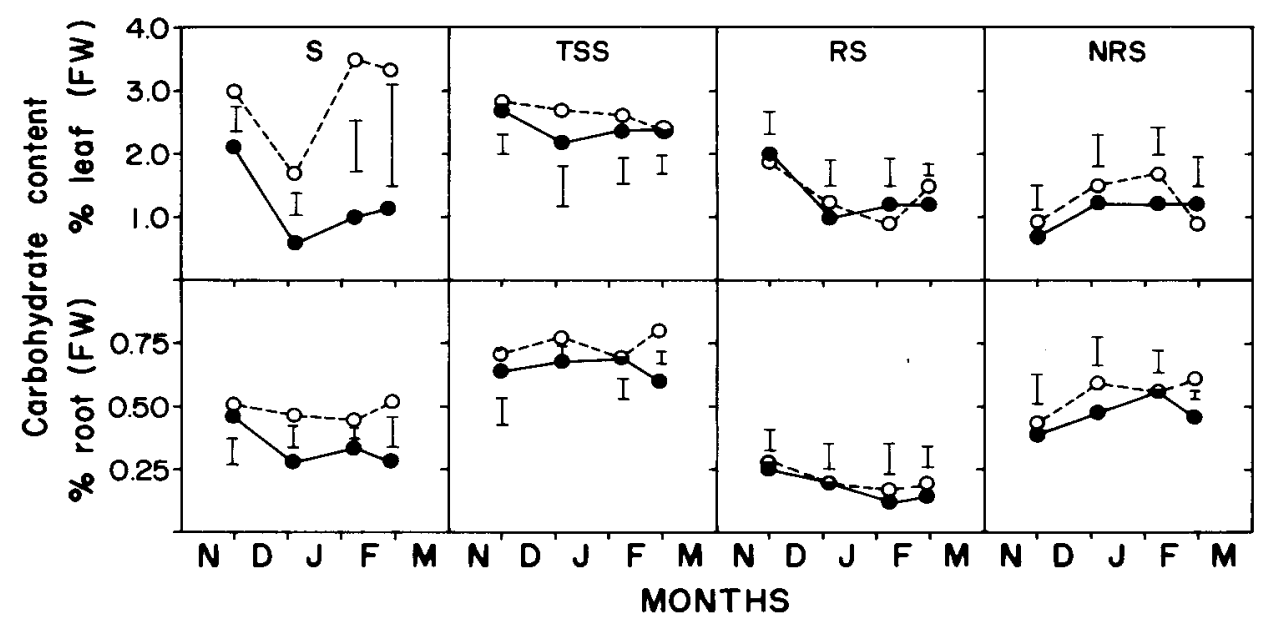

FIGURE 3 - Time course of content of starch (S), total soluble sugars (TSS), reducing sugars (RS) and non-reducing sugars (NRS) in leaves (upper) and in roots (lower) of fruiting (solid line) and de-fruited (dotted line) coffee trees, from early December 1987 through February 1988. Bars represent the least statistical difference at a given time, at $P=0.05$. Each point is a mean of five replicates. 


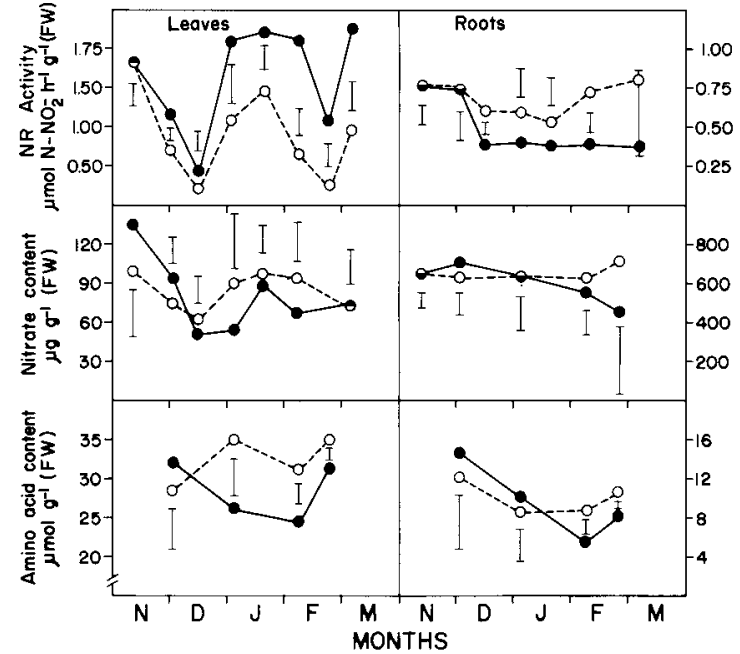

FIGURE 4 - Time course of nitrate reductase (NR) activity and content of nitrate and amino acids in leaves (left) and in roots (right) of fruiting (solid line) and de-fruited (dotted line) coffee trees, from November 1987 through early March 1988. Note the differences of scale. Bars represent the least statistical difference at a given time, at $P=$ 0.05 . Each point is a mean of five replicates.

This hypothesis is supported by the findings that NR activation is known to be associated not only with mobilisation of $\mathrm{NO}_{3}-\mathrm{N}$ from storage pools (Kronzucker et al., 1995), but mostly with a continued flow of $\mathrm{NO}_{3}$-N to leaves (Queiroz et al., 1993; Gojon et al., 1998). An increased flow of this anion might also be invoked to account for by the higher NR activity most of the time in fruiting over de-fruited trees, considering that bearing coffee plants take up and translocate mineral elements to shoots faster than the non-bearing ones (Cannel and Kimeu, 1971; Carvalho et al., 1993). Taking into account that high NR activity was a response to an increased flow of $\mathrm{NO}_{3}-\mathrm{N}$ to leaves, thus the inverse relation between NR activity and growth would simply be circumstantial, rather than being related to each other. In any case, because leaf $\mathrm{NO}_{3}-\mathrm{N}$ levels were not altered significantly by fruit
(Figure 4), it should be realised that the greater leaf NR activity in fruiting trees might have contributed to decrease the $\mathrm{NO}_{3}-\mathrm{N}$ content to levels similar to those of de-fruited trees. However, a higher leaf enzyme activity was not followed by a build-up of reduced $\mathrm{N}$ compounds. By contrast, the content of amino-N in both leaves and roots was depressed on certain occasions in fruiting trees (Figure 4), whilst $\mathrm{NH}_{4}-\mathrm{N}$ was not detected in coffee leaves during the present experiment, as already described by Da Matta et al. (1999). In this context, the decreased availability of amino$\mathrm{N}$ in vegetative parts of fruiting trees could have resulted from mobilisation of amino-N to developing fruits at the expense of vegetative organs, which may have contributed to some extent to depress growth rates in those trees in comparison to de-fruited plants (Figure 1).

Altogether, the data presented here indicated that much of the restrictive effects of fruiting on vegetative growth appeared to be associated to starch exhaustion, in addition to the outstanding effect of supra-optimum temperatures per se. Despite the higher amino-N levels in defruited over fruiting trees during most of the experimental period, differences were not large enough to have significantly contributed to increase growth rates in de-fruited trees. Finally, all the above mentioned relations must be cautiously considered, as growth necessarily integrates complex physiological and morphological changes along with the time, whereas instantaneous measurements of carbohydrates and $\mathrm{N}$ status from single leaves express a momentary plant performance.

\section{ACKNOWLEDGEMENTS}

The authors are indebted to $\mathrm{CNPq}$ (Conselho Nacional de Desenvolvimento Científico e Tecnológico, Brazil) and FINEP (Financiadora de Estudos e Projetos, Brazil) for financial support. Many thanks are due also to Dr. Raimundo S. Barros for his critical reading of the manuscript and helpful comments. 


\section{REFERENCES}

ALÈGRE, C. Climats et caféiers d'Arabie. Agronomie Tropicale, 14: 23-58, 1959.

BARROS, R.S. \& MAESTRI, M. Influência dos fatores climáticos sobre a periodicidade do crescimento vegetativo do café (Coffea arabica L.). Revista Ceres, 21: 268-279, 1974.

BARROS, R.S.; MAESTRI, M; VIEIRA, M. \& BRAGA FILHO, L.J. Determinação da área de folhas do café (Coffea arabica L. cv Bourbon Amarelo). Revista Ceres, 20:44-52, 1973.

BARROS, R.S.; MOTA, J.W.S.; DA MATTA, F.M. \& MAESTRI, M. Decline of vegetative growth in Coffea arabica $\mathrm{L}$. in relation to leaf temperature, water potential and stomatal conductance. Field Crops Research, 54: 6572, 1997.

BRAVO-C., M. \& FERNANDEZ, C.E. Respuesta de plantas jóvenes de café a la aplicación de tres nibeles de humedad en el suelo y dos fertilizantes nitrogenados. Turrialba, 14: 1523, 1964.

CAMPBELL, W.H. Nitrate reductase structure, function and regulation: bridging the gap between biochemistry and physiology. Annual Review of Plant Physiology and Plant Molecular Biology, 50: 277-303, 1999.

CANNEL, M.G.R. Effects of fruiting, defoliation and ring-barking on the accumulation and distribution of dry matter in branches of Coffea arabica in Kenya. Experimental Agriculture, 7: 63-74, 1971.

CANNEL, M.G.R. Physiology of the coffee crop. In: CLIFFORD, M.N. \& WILSON, K.C. (Eds.) Coffee: botany, bio chemistry and production of beans and beverage. New York, Croom Helm, 1985. p.109-134.

CANNEL, M.G.R. \& HUXLEY, P.A. Seasonal differences in the pattern of assimilate movement in branches of Coffea arabica L. Annals of Applied Biology, 64: 345-357, 1969.
CANNEL, M.G.R. \& KIMEU, B.S. Uptake and distribution of micro-nutrients in trees of Coffea arabica L. in Kenya as affected by seasonal climatic differences and the presence of fruits. Annals of Applied Biology, 68: 213230, 1971.

CARVALHO, C.H.S.; RENA, A.B.; PEREIRA, A.A. \& CORDEIRO, A.T. Relação entre a produção, teores de $\mathrm{N}, \mathrm{P}, \mathrm{K}, \mathrm{Ca}, \mathrm{Mg}$, amido e a seca de ramos do Catimor (Coffea arabica L.). Pesquisa Agropecuária Brasileira, 28: 665673, 1993.

CATALDO, D.A.; HAROON, M.; SCHRADER, L.E. \& YOUNGS, V.L. Rapid colorimetric determination of nitrate in plant tissue by nitration of salicylic acid. Communications on Soil Science Analysis, 6: 71-80, 1975.

CATALDO, D.A.; SCHRADER, L.E. \& YOUNGS, V.L. Analysis by digestion and colorimetric assay of total nitrogen in plant tissues high in nitrate. Crop Science, 14: 854856, 1974.

CLOWES, M.S.J. \& WILSON, J.H.H. The growth and development of lateral branches of Coffea arabica in Rhodesia. Rhodesian Journal of Agricultural Research, 15: 171-185, 1977.

DA MATTA, F.M.; AMARAL, J.A.T. \& RENA, A.B. Growth periodicity in trees of Coffea arabica in relation to nitrogen supply and nitrate reductase activity. Field Crops Research, 60: 223-229, 1999.

GINDEL, I. Ecological behavior of the coffee plant under semiarid conditions. Turrialba, 4:49-63, 1962.

GOJON, A.; DAPOIGNY, L.; LEJAY, L.; TILLARD, P. \& RUFTY, T.W. Effects of genetic modifications of nitrate reductase expression on ${ }^{15} \mathrm{NO}_{3}^{-}$uptake and reduction in Nicotiana plants. Plant, Cell and Environment, 21: 43-53, 1998. 
JAWORSKI, E.G. Nitrate reductase assay in intact plant tissues. Biochemical, Biophysical Research Communications, 43: 1274-1290, 1971.

KRONZUCKER, H.J.; SIDIQQI, M.Y. \& GLASS, A.D.M. Kinetics of $\mathrm{NO}_{3}^{-}$influx in spruce. Plant Physiology, 109: 319-326, 1995.

MAESTRI, M. \& BARROS, R.S. Coffee. In: ALVIM, P.T. \& KOZLOWSKI, T.T. (Eds.) Ecophysiology of tropical crops. New York, Academic Press, 1977. p.248-278.

McCREADY, R.M.; GUGGLOZ, J.; SILVEIRA, V. \& OWENS, H.S. Determination of starch and amylose in vegetables: application to peas. Analytical Chemistry, 22: 1156-1158, 1950.

MONTOYA, L.A.; SYLVAIN, P.G. \& UMAÑA, R. Effect of light intensity and nitrogen fertilization upon growth differentiation balance in Coffea arabica L. Coffee (Turrialba), 3: 97-108, 1961.

MOORE, S. \& STEIN, W.H. A modified ninhydrin reagent for the photometric determination of amino acids and related compounds. Journal of Biological Chemistry, 221: 907-913, 1954.

MOTA, J.W.S.; DA MATTA, F.M.; BARROS, R.S. \& MAESTRI, M. Vegetative growth in Coffea arabica L. as affected by irrigation, daylength and fruiting. Tropical Ecology, 38: 73-79, 1997.
NELSON, N. Colorimetric analysis for reducing sugars. Journal of Biological Chemistry, 153: $175,1944$.

NUNES, M.A.; BIERHUIZEN, J.F. \& PLOEGMAN, C. Studies on productivity of coffee. I. Effect of light, temperature and $\mathrm{CO}_{2}$ concentration on photosynthesis of Coffea arabica. Acta Botanica Neerlandica, 17: 93$102,1968$.

NUTMAN, F.J. The root system of Coffea arabica L. I. Root systems in typical soils of British East Africa. Empire Journal of Experimental Agriculture, 1: 271-284, 1933.

QUEIROZ, C.G.S.; RENA, A.B.; CORDEIRO, A.T. \& ALVES, J.D. Ritmo diurno na atividade da redutase do nitrato em folhas e raízes de Coffea arabica L. Pesquisa Agropecuária Brasileira, 28: 787-795, 1993.

RENA, A. B.; BARROS, R.S.; MAESTRI, M. \& SÖNDAHL, M.R. Coffee. In: SCHAFFER, B. \& ANDERSEN, P.C. (Eds.) Handbook of environmental physiology of fruit crops: subtropical and tropical crops. Boca Raton, CRC Press, 1994. v. II, p.101-122.

SOLOMONSON, L. P. \& BARBER, M. J. similatory nitrate reductase: functional properties and regulation. Annual Review of Plant Physiology and Plant Molecular Biology, 41: 225-253, 1990.

WORMER, T.M. \& EGABOLE, H.E. Visual scoring of starch in Coffea arabica L. II. Starch in bearing and non-bearing branches. Experimental Agriculture, 1: 41-54, 1965. 